Research

\title{
Molecular surveillance of mutations in the cytochrome $b$ gene of Plasmodium falciparum in Gabon and Ethiopia
} Tamirat Gebru ${ }^{1,2}$, Asrat Hailu ${ }^{3}$, Peter G Kremsner ${ }^{2,4}$, Jürgen FJ Kun ${ }^{4}$ and Martin P Grobusch*2,5

Address: ${ }^{1}$ Department of Medical Laboratory Technology, Faculty of Health Sciences, Haramaya University, Haramaya, Ethiopia, ${ }^{2}$ Medical Research Unit, Albert Schweitzer Hospital, Lambaréné, Gabon, ${ }^{3}$ Department of Microbiology, Immunology and Parasitology, Faculty of Medicine, Addis Ababa University, Addis Ababa, Ethiopia, ${ }^{4}$ Department of Parasitology, Institute of Tropical Medicine, University of Tübingen, Tübingen, Germany and ${ }^{5}$ Infectious Diseases Unit, Division of Clinical Microbiology and Infectious Diseases, National Health Laboratory Service and School of Pathology, Faculty of Health Sciences, University of the Witwatersrand, Johannesburg, South Africa

Email: Tamirat Gebru - tamiratgw2002@yahoo.com; Asrat Hailu - hailu_a2004@yahoo.com; Peter G Kremsner - peter.kremsner@unituebingen.de; Jürgen FJ Kun - juergen.kun@uni-tuebingen.de; Martin P Grobusch* - martin.grobusch@wits.ac.za

* Corresponding author

Published: 21 November 2006

Malaria Journal 2006, 5:II2 doi:I0.1I86/I475-2875-5-II2
Received: 01 September 2006

Accepted: 21 November 2006

This article is available from: http://www.malariajournal.com/content/5/1/1 I2

(C) 2006 Gebru et al; licensee BioMed Central Ltd.

This is an Open Access article distributed under the terms of the Creative Commons Attribution License (http://creativecommons.org/licenses/by/2.0), which permits unrestricted use, distribution, and reproduction in any medium, provided the original work is properly cited.

\begin{abstract}
Background: Atovaquone is part of the antimalarial drug combination atovaquone-proguanil (Malarone ${ }^{\circledR}$ ) and inhibits the cytochrome bc, complex of the electron transport chain in Plasmodium spp. Molecular modelling showed that amino acid mutations are clustered around a putative atovaquone-binding site resulting in a reduced binding affinity of atovaquone for plasmodial cytochrome $b$, thus resulting in drug resistance.
\end{abstract}

Methods: The prevalence of cytochrome $b$ point mutations possibly conferring atovaquone resistance in Plasmodium falciparum isolates in atovaquone treatment-naïve patient cohorts from Lambaréné, Gabon and from South Western Ethiopia was assessed.

Results: Four/40 (10\%) mutant types (four different single polymorphisms, one leading to an amino acid change from $M$ to $I$ in a single case) in Gabonese isolates, but all $|4| /|4|$ isolates were wild type in Ethiopia were found.

Conclusion: In the absence of drug pressure, spontaneous and possibly resistance-conferring mutations are rare.

\section{Background}

The genetic complexity of Plasmodium falciparum and its ability to generate mutant variants in particular makes it a strikingly successful pathogen. Single nucleotide polymorphisms (SNPs) contribute largely to its genetic variability [1]. P. falciparum undergoes mutations in respective target genes, thus resulting in variations of the encoded proteins which facilitate escape from particular antimalarial compounds.
The mitochondrion plays a functional key role in the electron transport system of the parasite [2]. By binding to the cytochrome bc1 complex of the parasite, atovaquone, which was introduced in a fixed combination with proguanil hydrochloride as an antimalarial drug in the late 1990s [3], leads to the collapse of the mitochondrial membrane potential at far lower concentrations than that at which the respective mammalian system is affected $[4,5]$. Its mode of action is unique in targeting parasite 
mitochondria selectively, thus inhibiting parasitic oxygen consumption [6] without affecting the host's mitochondrial functions [7]. In addition to electron transport inhibition, atovaquone acts through destabilization of the cytochrome bc1 complex, thus causing proton leakage to occur through this site. Proguanil enhances this destabilization $[8,9]$.

Atovaquone has been a successful drug against several eukaryotic microbial parasites [10], including Toxoplasma gondii [11] and Pneumocystis carinii (now jirovecii) [12]. However, when used as a single agent against malaria, the drug has shown a high rate of treatment failures $[13,14]$.

Emergence of parasite resistance to atovaquone due to point mutations in the cytochrome $b$ gene has been described [3] and confirmed in vitro and in vivo [15]. When used as a single agent, slow uptake and high lipophilicity of the drug may result in a prolonged period of parasite exposure to suboptimal atovaquone concentrations [8]. In consequence, atovaquone-resistant parasites appear to emerge frequently due to this suboptimal therapy $[13,14,16]$.

Due to the emergence of resistance against atovaquone as a single therapeutic agent, inclusion of proguanil as a synergistic agent with atovaquone has been developed in order to minimize the occurrence of drug resistance [17]. The combination of atovaquone and proguanil (Malarone $e^{\circledR}$ ) has been found to be effective in treating malaria [13]. While proguanil by itself had no effect on electron transport or mitochondrial membrane potential, it significantly enhanced atovaquone efficacy when used in combination $[7,8]$.

Proguanil, in its prodrug form, acts in synergy with atovaquone by lowering the effective concentration at which atovaquone leads to a collapse of the mitochondrial membrane potential in malaria parasites. The net result is a much lower incidence of treatment failure and resistance emergence, as it has been observed in clinical trials [8]. However, mutant strains of $P$. falciparum were also resistant to the synergistic effects of atovaquone/proguanil combination [7].

Atovaquone/proguanil is in use as an effective, safe and acceptable prophylaxis and oral treatment for uncomplicated malaria in adults and children [18-23]. As it has been already proposed as first-line therapy in Africa [24], the background mutation rate in an area of Eastern and Western Africa (Ethiopia and Gabon) where atovaquone/ proguanil has not been widely used outside of treatment studies was determined in this study [25].

\section{Materials and methods}

The clinical material stemmed from clinical studies at both study sites, and ethical approval was obtained from the respective Ethics Committees of Addis Ababa University and of the International Foundation of the Albert Schweitzer Hospital (HAS). Samples from the Ethiopian site were collected at the Jimma Health Center from patients with uncomplicated malaria as described earlier [26]. Forty other samples were collected at the HAS from uncomplicated malaria cases in a study to validate lowdose chemotherapy [27].

\section{DNA analysis}

The DNA extraction procedure was performed using QIA amp $^{\circledast}$ DNA Mini Kit (QIAGEN, Hilden, Germany), according to the manufacturer's instruction. The samples were analysed using nested PCR and DNA sequencing to detect variation in the $c y t b$ gene.

To obtain information about mutations in the cytochrome $b$ gene we analysed 40 parasite samples from Lambaréné, Gabon. From these samples, the primers Cytb1 (5'-CTCTATTAATTTAGTTAAAGCACAC-3') and Cytb4 (5'-ACAGAATAATCTCTAGCACC-3') were used to amplify a fragment of 939 bp containing the $c y t b$ gene. The obtained fragments were analysed on a 1\% agarose gel for purity. Gels were stained with $\mathrm{CYBR}^{\circledR}$ GREEN I nucleic acid gel stain (Cambrex Bioscience, East Rutherford, NJ, USA) and visualized on a dark reader transilluminator (Clare Chemical Research, Dolores, CO, USA). Prior to sequencing, the amplified DNA was purified by a PCR purification kit (E.Z.N.A. ${ }^{\circledR}$ Cycle - Pure Kit, Erlangen, Germany) following the supplier's instructions. Then, the DNA sequence was determined using Big Dye $1.1^{\circledR}$ (Applied Biosystems, Foster City, CA, USA) and purified again by DNA grade Sephadex ${ }^{\circledast}$ (Amersham Biosciences AB, Uppsala Sweden). Strand separation was done on an Applied Biosystems Genetic Analyzer 3100 (Foster City, CA, USA). DNA sequences were finally analysed with the Bio-edit sequence alignment program [28] to detect point mutation.

141 samples from Ethiopia were subjected to PCR using the primers CytbF (5'-GGGTATGATACAGCATTAAAAATAC-3') and Cytb4 resulting in a 349 bp fragment. Here we were interested only in the 3 ' end of the gene since no mutations were detected in the 5 ' end in the Gabonese samples. The samples were prepared as described above.

\section{Results and discussion}

No mutations were detected in the Ethiopian samples. Single nucleotide polymorphisms (one in each of 4 samples): T676A, C689T; T760G and G925T were detected in the Gabonese samples. Only the latter exchange results 
also in an amino acid change $\mathrm{M}$ to I in one isolate. There were no mutations detected in codon 268 .

The antimalarial activity of atovaquone and its enhancer proguanil has been assessed in in vivo and in vitro drug sensitivity tests, as well as in genetic studies in different countries. In a study from Vietnam, it has been reported that the combination of atovaquone with proguanil (AP) yielded an overall cure rate of $86 \%$ to treat recrudescent $P$. falciparum infections that had occurred after primary treatment with other antimalarials. In their study, the authors recommended $\mathrm{AP}$ as a safe and promising alternative treatment for $P$. falciparum infections in South-East Asia [29].

In another study, it was described that atovaquone has shown better in vitro response as compared to other eight antimalarials among the $P$. falciparum strains collected from 14 countries in South and Central Africa. It was suggested in the same study that atovaquone has a potential to be used as an alternative antimalarial in Africa better than Asian countries [30].

As with other antimalarials, concern about rapid emergence of drug-resistant strains arose following initial reports of definite, or possible, resistance-conferring polymorphisms of the cytochrome b gene found in treatmentfailing $P$. falciparum.

Mutations (Tyr268Asn and Tyr268Ser) of the P. falciparum cytochrome $b$ gene were reported in cases of malarone treatment failure $[15,31]$. Sequencing of the cytochrome bencoding region of mitochondrial DNA together with DNA samples from $P$. falciparum control strains yielded a change from TAT to AAT in codon 268 (Y268N), specifying a change from tyrosine (Tyr) to asparagine (Asn) in an isolate from a Nigerian patient clinically (R1) and in vitro resistant to atovaquone/proguanil [31].

A different mutation in this codon (TAT to TCT in codon 268) specifying a change from tyrosine to serine: Y268S was found in a Thai patient with acute atovaquone and pyrimethamine treatment failure [15], and it was also suggested that a change of Tyr268 (Tyr) to Ser268 (Ser) may be a sufficient cause for atovaquone/proguanil treatment failure [32]. Therefore, mutations at codon 268 of the parasite cytochrome bc1 gene have been recognized as potential markers to measure and control the emergence of resistance against atovaquone/proguanil treatment [33].

Further single or double amino acid mutations were generated from a cloned line exposed to various atovaquone concentrations in vitro and leading to a significant reduction in parasite susceptibility to atovaquone. These mutations are M133I, K272R, P275T, and G280D [15]. Thus, multiple mutations in the cytochrome $b$ gene are assumed to be more useful in surveillance for atovaquone resistance. Methods that can pick up multiple mutations (such as DNA sequencing) will be appropriate for screening [34]. However, in vivo atovaquone resistance may not always be associated with previously identified cytochrome $b$ gene point mutations [35] since failure in drug action can also be resulting from metabolic diversion to the alternative respiratory pathway of the parasite [36].

Sequencing of the cytochrome $\mathrm{b}$ gene of $P$. falciparum from a patient returning from Mali with Malarone ${ }^{\circledast}$ treatment failure revealed a point mutation at codon 268 (Tyr268Ser). However, there was no detection of alterations at codon 133 of the strains which showed in vivo treatment failure even though it has been found, in the same study, in all strains that showed atovaquone resistance in vitro [33].

These results underline that in the absence of drug pressure, spontaneous and possibly resistance-conferring mutations are rare. Assessing the activity of atovaquone using in vitro drug sensitivity assay and DNA sequencing of the cytochrome $b$ gene, Basco and colleagues (2003) did not report any mutations in the target gene in the $P$. falciparum isolates collected from 37 Cameroonians [37]. In addition, using a low nanomolar range of atovaquone, none of the isolates displayed any evidence for atovaquone resistance in vitro. In another study, the commonly associated cytochrome b codon 268 mutation has been assessed in 100 isolates of $P$. falciparum from Northern Ghana. None of these isolates exhibited mutation at this position [38]. Pimentel et al. (2006) [39] studied blood samples from 249 atovaquone-proguanil treatment-naïve children and found a prevalence of possibly resistance-conferring polymorphisms in codon 268 in a frequency of $<0.77 \%$ (99\% significance level).

A low prevalence of Ser268 (0.96\%) and Asn268 (0.77\%) was also reported in other imported isolates of $P$. falciparum in Europe [32].

Single nucleotide polymorphisms occurred in the Gabonese samples in four of the forty samples (T676A, C689T, T760G, G925T), of which only one led to an amino acid change which has not been associated before with resistance in vitro and/or in vivo, and which may well not be resistance-conferring. No mutations were detected in the isolates from Ethiopia. This is consistent with those of previous studies from various African countries [37,38]. Musset et al. (2006) [40] genotyped 477 atovaquoneunexposed African P. falciparum isolates and found exclusively wild types. Berry et al. (2006) [41] found polymorphisms in 12/135 (8.9\%) of unexposed West and Central African isolates; an overall rate which is consistent with 
ours. Nine were only transitions and therefore 'silent'; only three led to transversions with amino acid changes; again, a rate very to the one presented in this paper.

\section{Conclusion}

In the absence of drug pressure, spontaneous and possibly resistance-conferring mutations are rare. In line with the findings presented here, an elevated rate of resistance against atovaquone is not reported in most of similar studies in endemic areas and in the absence of drug pressure. However, a higher rate of resistance in the future is likely to occur under drug pressure $[16,32,36]$. As this would be in accordance with the experience with aminoquinoline and sulpha drugs, possibly, probably and definitely resistance-confirming polymorphisms (single, or in combination) will occur with almost certainty.

\section{Authors' contributions}

TG carried out the molecular genetic studies, helped to design the study and contributed to the draft of the manuscript.

AH participated in the design of the study and helped to finalise the manuscript.

PGK participated in the design of the study and helped to finalise the manuscript.

JFK contributed to the molecular genetic studies, helped to design the study and contributed to draft the manuscript.

MPG conceived of the study and contributed to the draft of the manuscript.

\section{Acknowledgements}

We would like to acknowledge the Prof. Josef and Erika Hesselbach Stiftung, the German Academic Exchange Service and Addis Ababa University for the financial support given to TG. We thank Velia Grummes and Andrea Weierich, Institute of Tropical Medicine, Tübingen University, for technical support.

\section{References}

I. Meyer CG, May J, Arez AP, Gil JP, do Rosario V: Genetic diversity of Plasmodium falciparum: asexual stages. Trop Med Int Health 2002, 7:395-408.

2. Krungkrai J: The multiple roles of the mitochondrion of themalarial parasite. Parasitology 2004, I 29:5 I I-524.

3. Looareesuwan S, Chulay JD, Canfield CJ, Hutchinson DB: Malarone (atovaquone and proguanil hydrochloride): a reviewof its clinical development for treatment of malaria. MalaroneClinical Trials Study Group. Am J Trop Med Hyg 1999, 60:533-541.

4. Fry M, Pudney $M$ : Site of action of the antimalarial hydroxynaphthoquinone, 2-[trans-4-(4ф-chlorophenyl) cyclohexyl]3-hydroxy-I,4-naphthoquinone (566C80). Biochem Pharmacol 1992, 43:1545-1553.

5. Mather MW, Darrouzet E, Valkova-Valchanova M, Cooley JW, Mclntosh MT, Daldal F, Vaidya AB: Uncovering the molecular mode of action of the antimalarial drug atovaquone using a bacterial system. J Biol Chem 2005, 280:27458-27465.
6. Suswam E, Kyle D, Lang-Unnasch N: Plasmodium falciparum: The effects of atovaquone resistance on respiration. Exp Parasitol 2001, 98:180-187.

7. Srivastava IK, Morrisey JM, Darrouzet E, Daldal F, Vaidya AB: Resistance mutations reveal the atovaquone-binding domain of cytochrome b in malaria parasites. Mol Microbiol 1999, 33:704-7|I.

8. Srivastava IK, Vaidya $A B: A$ mechanism for the synergisticantimalarial action of atovaquone and proguanil. Antimicr Agents Chemother 1999, 43:1334-1339.

9. Murphy AD, Lang-Unnasch N: Alternative oxidase inhibitorspotentiate the activity of atovaquone against Plasmodium falciparum. Antimicrob Agents Chemother 1999, 43:65I-654.

10. Srivastava IK, Rottenberg H, Vaidya AB: Atovaquone, abroad spectrum antiparasitic drug, collapses mitochondrial membranepotential in a malarial parasite. J Biol Chem 1997, 272:396I-3966.

II. Kovacs JA: Efficacy of atovaquone in treatment of toxoplasmosis in patients with AIDS. The NIAID-Clinical Center Intramural AIDS Program. Lancet 1992, 340:637-638.

12. Hughes W, Leoung G, Kramer F, Bozzette SA, Safrin S, Frame P, Clumeck N, Masur H, Lancaster D, Chan C, Lavelle J, Rosenstock J, Falloon J, Feinberg J, LaFon S, Rogers M, Sattler F: Comparison of atovaquone $(566 \mathrm{C} 80)$ with trimethoprim sulfamethoxazole to treat Pneumocystis carinii pneumonia in patients with AIDS. New Engl J Med 1993, 328:|52|-|527.

13. Looareesuwan S, Viravan C, Webster HK, Kyle DE, Hutchinson DBA, Canfield C): Clinical studies of atovaquone, alone or in combination with other antimalarial drugs, for treatment of acute uncomplicated malaria in Thailand. Am J Trop Med Hyg 1996, 54:62-66.

14. Chiodini PL, Conlon CP, Hutchinson DB, Farquhar JA, Hall AP, Peto $T E$, Birley H, Warrell DA: Evaluation of atovaquone in the treatment of patients with uncomplicated Plasmodium falciparum malaria. J Antimicrob Chemother 1995, 36: I073-1078.

15. Korsinczky M, Chen N, Kotecka B, Saul A, Rieckmann K, Cheng Q: Mutations in Plasmodium falciparum cytochrome $b$ that are associated with atovaquone resistance are located at a putative drug-binding site. Antimicrob Agents Chemother 2000, 44:2100-2108.

16. Kuhn S, Gill MJ, Kain KC: Emergence ofatovaquone-proguanil resistance during treatment of Plasmodium falciparum malaria acquired by a non-immune north American traveller to west Africa. Am J Trop Med Hyg 2005, 72:407-409.

17. Canfield C], Pudney $M$, Gutteridge WE: Interactions of atovaquone with other antimalarial drugs against Plasmodium falciparum in vitro. Exp Parasitol 1995, 80:373-38I.

18. Radloff PD, Philipps J, Nkeyi M, Hutchinson D, Kremsner PG: Atovaquone and proguanil for Plasmodium falciparum malaria. Lancet 1996, 347:|5||-1514.

19. Hogh B, Clarke PD, Camus D, Nothdurft HD, Overbosch D, Gunther M, Joubert I, Kain KC, Shaw D, Roskell NS, Chulay JD, Malarone International Study Team: Atovaquone-proguanil versus chloroquine-proguanil for malaria prophylaxis in non-immune travellers: a randomised, double-blind study. Lancet 2000, 356: $1888-1894$

20. Overbosch D, Schilthuis H, Bienzle U, Behrens RH, Kain KC, Clarke PD, Toovey S, Knobloch J, Nothdurft HD, Shaw D, Roskell NS, Chulay JD, Malarone International Study Team: Atovaquone-proguanilversus mefloquine for malaria prophylaxis in nonimmune travelers:Results from a randomized, doubleblind study. Clin Infect Dis 2001, 33:1015-1021 [http://www.jour nals.uchicago.edu/CID/journal/issues/v33n7/010125/ 010125.text.html?erFrom=-5188934061545476792Guest-fn I].

21. McKeage K, Scott L: Atovaquone/proguanil: a review of itsuse for the prophylaxis of Plasmodium falciparum malaria. Drugs 2003, 63:597-623.

22. Camus D, Djossou F, Schilthuis HJ, Hogh B, Dutoit E, Malvy D, Roskell NS, Hedgley C, De Boever EH, Miller GB: Atovaquone-proguanil versus chloroquine-proguanil for malaria prophylaxis in nonimmune pediatric travellers: results of an international, randomized, open-label study. Clin Infect Dis 2004, 38: I716-1723.

23. Thybo S, Gjorup I, Ronn AM, Meyrowitsch D, Bygberg IC: Atovaquone-proguanil (malarone): an effective treatment for uncomplicated Plasmodium falciparum malaria in travelers from Denmark. J Travel Med 2004, I I:220-223. 
24. Shretta R, Brugha R, Robb A, Snow RW: Sustainability, affordability, and equity of corporate drug donations: the case of Malarone. Lancet 2000, 355:1718-1720.

25. Lell B, Luckner D, Ndjave M, Scott T, Kremsner PG: Randomised placebo-controlled study of atovaquone plus proguanil for malaria prophylaxis in children. Lancet 1998, 35 1:709-713.

26. Gebru-Woldearegai T, Asrat H, Grobusch MP, Kun JFJ: Molecular surveillance of mutations in DHFR and DHPS genes of Plasmodium falciparum in Ethiopia. Am J Trop MedHyg 2005, 73:1131-1134.

27. Kun JFJ, Lehman LG, Lell B, Schmidt-Ott JR, Kremsner PG: Low-dose treatment with sulfadoxine-pyrimethaminecombinations selects for drug-resistant Plasmodium falciparum strains. Antimicrob Agents Chemother 1999, 43:2205-2208.

28. [http://www.mbio.ncsu.edu/BioEdit/bioedit.html]. [last accessed on 8 August 2006]

29. Giao PT, de Vries PJ, Hung LQ, Binh TQ, Nam NV, Kager PA: Atovaquone-proguanil for recrudescent Plasmodium falciparum in Vietnam. Ann Trop Med Parasitol 2003, 97:575-580.

30. Gay F, Bustos D, Traore B, Jardinel C, Southammavong M, Ciceron L, Danis MM: In vitro response of Plasmodium falciparum to atovaquone and correlation with other antimalarials: comparison between African and Asian strains. Am J Trop Med Hyg 1997, 56:315-317.

31. Fivelman QL, Butcher GA, Adagu IS, Warhurst DC, Pasvol G: Malarone treatment failure and in vitro confirmation of resistance of Plasmodium falciparum isolate from Lagos, Nigeria. Malar J 2002, I:I.

32. Wichmann $\mathrm{O}$, Muehlberger $\mathrm{N}$, Jelinek $\mathrm{T}$, Alifrangis $\mathrm{M}$, Peyerl-Hoffmann G, Muhlen M, Grobusch MP, Gascon J, Matteelli A, Laferl H, Bisoffi Z, Ehrhardt S, Cuadros J, Hatz C, Gjorup I, McWhinney P, Beran J, daCunha S, Schulze M, Kollaritsch H, Kern P, Fry G, Richter J, European Network on Surveillance of Imported Infectious Diseases: Screening for mutations related to atovaquone/proguanil resistance in treatment failures and other imported isolates of Plasmodium falciparum in Europe. J Infect Dis 2004, 190: I54I-I546.

33. Schwöbel B, Alifrangis M, Salanti A, Jelinek T: Different mutation patterns of atovaquone resistance to Plasmodium falciparum in vitro and in vivo: rapid detection of codon 268 polymorphisms in the cytochrome $b$ as potential in vivo resistance marker. Malar J 2003, 2:5

34. Meshnick SR, Trumpower B: Multiple cytochrome b mutationsmay cause atovaquone resistance (comment). J Infect Dis 2005, 191:822

35. Wichmann O, Muehlen M, Gruss H, Mockenhaupt FP, Suttorp N Jelinek T: Malarone treatment failure not associated with previously described mutations in the cytochrome b gene. Malar J 2004, 3:14.

36. Thapar MM, Gil JP, Bjorkman A: In vitro recrudescence of Plasmodium falciparum parasites suppressedto dormant state by atovaquone alone and in combination with proguanil. Trans $R$ Soc Trop Med Hyg 2005, 99:62-70.

37. Basco LK: Molecular epidemiology of malaria in Cameroon. xvii. Baseline monitoring of atovaquone-resistant plasmodium falciparum by in vitro drug assays and cytochcrome $b$ gene sequence analysis. Am J Trop Med Hyg 2003, 69:179-I83.

38. Muehlen M, Schreiber J, Ehrhardt S, Otchwemah R, Jelinek T, Bienzle U, Mockenhaupt FP: Short communication: prevalence of mutations associated with resistance to atovaquone and to the antifolate effect of proguanil in Plasmodium falciparum isolates from northern Ghana. Trop Med Int Health 2004, 9:361-363.

39. Pimentel S, Nogueira F, Benchimol C, Quinhentos V, Bom J, Varandas $\mathrm{L}$, do Rosario V, Bernadino L: Detection of atovaquone-proguanil resistance conferring mutations in Plasmodium falciparum cytochrome b gene in Luanda, Angola. Malar J 2006 5:30.

40. Musset L, Pradines B, Parzy D, Durand R, Bigot P, Le Bras J: Apparent absence of atovaquone/proguanil resistance in 477 Plasmodium falciparum isolates from untreated French travellers. J Antimicrob Chemother 2006, 57: I I0-II5.

4I. Berry A, Senescau A, Levievre J, Benoit-Vical F, Fabre R, Marchou B, Magnaval JF: Prevalence of Plasmodium falciparum cytochrome b gene mutations in isolates imported from Africa, and implications for atovaquone resistance. Trans $R$ Soc Trop Med Hyg 2006, 100:986-988.
Publish with Biomed Central and every scientist can read your work free of charge

"BioMed Central will be the most significant development for disseminating the results of biomedical research in our lifetime. "

Sir Paul Nurse, Cancer Research UK

Your research papers will be:

- available free of charge to the entire biomedical community

- peer reviewed and published immediately upon acceptance

- cited in PubMed and archived on PubMed Central

- yours - you keep the copyright 